Dissertações e teses - REsumos

\title{
Andando no fio da navalha: riscos e armadilhas na confecção de laudos psicológicos para a justiça*
}

\section{Walking on the razor's edge: avoiding ethical pitfalls while performing psychological evaluations for the court}

\author{
Sidney Kiyoshi Shine ${ }^{1}$
} Shine SK. Andando no fio da navalha: riscos e armadilhas na confecção de laudos psicológicos para a justiça. Saúde,
Ética \& Justiça. 2009;14(1)40-1. [Resumo]

Resumo: A perícia psicológica é um recurso previsto no Código do Processo Civil para instruir litígios processuais em Vara de Família. O laudo psicológico como documento escrito resultante da avaliação psicológica pericial deve preencher requisitos formais para ser aceito enquanto prova pericial pelo Direito. O laudo psicológico deve preencher requisitos técnicos e éticos para ser considerado um trabalho cientificamente aceitável na Psicologia. Estudou-se uma amostra de 31 representações (denúncias éticas) contra psicólogos que produziram laudos no período de 1997 a 2005 julgados pelo Conselho Regional de Psicologia - 06. As categorias de análise criadas a partir da literatura especializada permitiram: conhecer o motivo da representação, identificar o profissional representado e discriminar o que o laudo deve conter para ser considerado um "operador de verdade". Os resultados revelaram uma amostra heterogênea. Havia apenas quatro laudos psicológicos periciais sendo que os demais documentos eram declarações, pareceres e relatórios de atendimento psicoterapêutico. O maior número de representações partiu de pessoas que não foram atendidas ou avaliadas por estes psicólogos. O grupo profissional que recebeu o maior número de representações foi o dos que realizaram psicodiagnósticos ou terapias de crianças (21 profissionais). Do total, 20 representações foram arquivadas ou terminaram em absolvição. Oito profissionais foram condenados por fazerem afirmações a respeito de pessoas sem fundamentação técnica condizente. Três casos prescreveram. Concluiu-se que existe desconhecimento por grande parte da categoria sobre o trabalho desenvolvido no campo da Psicologia Jurídica, especificamente na Vara da Família. O psicólogo judiciário que atua nesta área produzindo laudos não é o profissional mais representado no CRP-06. Quase dois terços dos trabalhos escritos foram considerados isentos de falhas técnicas ou éticas. Os laudos considerados aceitáveis pelos padrões da profissão também o são para fim de prova judicial. As falhas mais graves não são da ordem da linguagem (problemas semânticos ou sintáticos), como também não são de dificuldade

\footnotetext{
* Tese de doutorado - Instituto de Psicologia, Universidade de São Paulo. Orientadora: Audrey Setton de Souza. São Paulo, 2009.

1 Psicólogo judiciário, psicanalista e professor em Curso de Especialização em Psicologia Jurídica. Especialista em Psicologia Clínica e Jurídica pelo CFP, Mestre e Doutor pela Psicologia da USP.

EnderEço PARA CORRESPondÊNCIA: Sidney Kiyoshi Shine. Rua Bertioga, 46. São Paulo, SP. 04141-100. E-mail: shine@usp.br
} 
de comunicação da matéria psicológica ao leitor leigo, mas de estratégias de avaliação psicológica equivocadas. Os documentos escritos foram gerados a partir de atendimentos que desconsideraram aspectos importantes das famílias envolvidas em litígios processuais. Atribuiu-se tais falhas à atuação contratransferencial, falta de familiaridade com o trabalho com famílias e desconhecimento das relações de poder no trato com advogados e juízes. Alerta-se para o risco ético de se prescrever encaminhamentos jurídicos (sentenças) como resultado da avaliação psicológica, extrapolando o objeto e o objetivo da Psicologia. Reconhece-se o processo de normalização que é efetivado pela avaliação psicológica para fim de normatização da conduta pelo Poder Judiciário como forma de dirimir o conflito social. A atuação das Comissões de Ética dos Conselhos Regionais e Federal possui importante papel para garantir o exercício da cidadania e a normatização da prática psicológica.

Descritores: Laudo psicológico. Prova pericial. Infrações éticas. Avaliação psicológica. Psicologia jurídica.

Shine SK. Walking on the razor's edge: avoiding ethical pitfalls while performing psychological evaluations for the court. Doutorado (tese). Instituto de Psicologia da Universidade de São Paulo. Orientadora: Audrey Setton de Souza. São Paulo, 2009. Saúde, Ética \& Justiça. 2009;14(1)40-1. [Abstract].

Abstract: Psychological evaluation is a legal asset in the due process of Family Law litigations. It must fulfill certain requirements to be accepted as a means to provide truth for the justice. It must present ethical and technical requirements to be considered a result of sound recognized psychological practice. $31 \mathrm{com}$ plaints of professional misconduct relating to the producing of psychological evaluation documents for Family Law courts were reviewed. These complaints were filed with Professional Board for Psychology - 06 and processed during 1997 and 2005. Categories of analyses were devised through available scientific literature in the field. The reasons for the complaint, the identification of the respondent (the person that the complaint is filed against) group and the criteria to review the contested document were analysed. The result shows different kinds of written documents but only three complete psychological evaluations performed for the court. The largest group of respondents were clinical child psychologists (21 respondents). 20 complaints were either dismissed or considered that a rule violation was not established. Eight psychologists were found responsible of Ethical Principles of Psychologists and Code of Conduct violation by making statements about people without sufficient scientific basis. Three cases expired. There is a general lack of knowledge about forensic psychological activities in Family Law courts. The forensic psychologist whose activity is to perform child custody evaluations is not the prevalent group of respondents. Almost two thirds of all the contested written reports were considered flawless. Psychological evaluations contested but not sanctioned were found valid and useful in court. Semantic or syntax problems of language or incompetence to convey psychological subject to lay people were not the basis of filed complaints. There seems to be problems with psychological evaluation strategies instead. Important dynamic family issues were ignored leading to faulty conclusions stated on written reports. Acting out of countertransference feelings, lack of experience in work with families involved in justice, and lack of knowledge of the power struggle in dealing with lawyers and judges are thought to be reasons for the misconduct. A warning is made against psychological evaluation that addresses the merit of the case, thus performing an act alien to the object and objective of psychological practice. It is recognized that psychological evaluation leads to the normalization of human conduct then ruled acceptable or not through legal standards. Social conflicts should be ruled by courts and not by psychologists. The works of Professional Board of Psychology both regional and federal are of paramount importance for the active citizenship and responsible provision of psychological services. 


\title{
Uso de álcool por vítimas de homicídio no município de São Paulo*
}

\section{The consumption of alcohol by homicide victims in the city of Sao Paulo}

\author{
Gabriel Andreuccetti ${ }^{1}$
}

Andreuccetti G. Uso de álcool por vítimas de homicídio no município de São Paulo. Saúde, Ética \& Justiça. 2009;14(1)423. [Resumo]

Resumo: Introdução - o consumo excessivo de álcool é considerado um grave problema de saúde pública e apontado como um importante facilitador das situações de violência, o que sugere uma forte associação entre a ingestão de bebidas alcoólicas e a vitimização por homicídio. O objetivo deste estudo foi analisar a associação entre o uso de álcool e a vitimização por homicídio em indivíduos autopsiados nos postos médico-legais do município de São Paulo. Métodos - Dados de 2042 vítimas de homicídio no ano de 2005 foram levantados a partir dos laudos necroscópicos obtidos dos arquivos do Instituto Médico Legal de São Paulo. As informações coletadas foram: sexo, idade, grupo étnico, meio de perpetração da morte, concentração de álcool no sangue das vítimas e circunstâncias dos homicídios, como o local, data e horário da morte. Resultados: O álcool estava presente em amostras de sangue de $43 \%$ das vítimas, com uma média de alcoolemia de 1,55 $\pm 0,86 \mathrm{~g} / \mathrm{l}$. A prevalência de alcoolemia positiva foi maior entre os homens $(44,1 \%)$ do que entre as mulheres (26,6\%), $p<0,01$. As armas de fogo causaram a maior parte das mortes $(78,6 \%)$ e o consumo de álcool foi maior entre as vítimas de homicídio cujo meio utilizado foi a arma branca $(p<0,01)$. Houve uma maior proporção de vítimas alcoolizadas aos finais de semana do que durante os dias da semana $(56,4$ e 38,5 , respectivamente; $\mathrm{p}<0,01$ ) e foi encontrada uma correlação positiva entre as taxas de homicídio e a média de concentração de álcool no sangue para a área Central da cidade $(\mathrm{rs}=0,90 ; \mathrm{p}<0,01)$. Conclusões - Os resultados demonstram a magnitude da influência do álcool como fator de contribuição para a vitimização por homicídio no maior centro urbano da América do Sul, fornecendo subsídios para políticas públicas e estudos futuros com o objetivo de prevenir os homicídios e a violência relacionada ao consumo de álcool.

Descritores: Etanol. Violência. Homicídio. Vitimização. Alcoolemia.

\footnotetext{
* Dissertação de mestrado - Faculdade de Medicina da Universidade de São Paulo. Orientador: Prof. Dr. Heráclito Barbosa de Carvalho. São Paulo, 2009.

1 Mestre pelo Departamento de Medicina Preventiva da Faculdade de Medicina da USP.
} 
Andreuccetti G. The consumption of alcohol by homicide victims in the city of Sao Paulo. Mestrado (dissertação) - Faculdade de Medicina da Universidade de São Paulo. Orientador: Prof. Dr. Heráclito Barbosa de Carvalho. São Paulo, 2009. Saúde, Ética \& Justiça. 2009;14(1)42-3. [Abstract].

AвStRact: Introduction - the excessive consumption of alcohol is a serious public health issue and a major factor in triggering violent situations, which suggests a strong association between alcohol ingestion and becoming a victim of homicide. The aim of this study was to assess the association between alcohol use and victimization by homicide in individuals autopsied at the Institute of Legal Medicine in Sao Paulo, Brazil. Methods: Data from 2,042 victims of homicides in 2005 were obtained from medical examiner reports. The victim's gender, age, ethnicity, and blood alcohol concentration (BAC) information were collected. The method of death and homicide circumstances, as well as the date, time and place of death were also studied. Results: Alcohol was detected in blood samples of $43 \%$ of the victims, and mean BAC lev- els were $1.55 \pm 0.86 \mathrm{~g} / \mathrm{L}$. The prevalence of positive BAC levels was higher among men $(44.1 \%)$ than women $(26.6 \%), p<0.01$. Firearms caused most of the deaths (78.6\%) and alcohol consumption was greater among victims of homicide by sharp weapons $(p<0.01)$. A greater proportion of victims with positive BAC were killed on weekends compared to weekdays ( 56.4 and $38.5 \%$, respectively; $p<0.01$ ), and the correlation between homicide rates and the average BAC for the central area of the city was positive ( $r s=0.90 ; p<0.01)$. Conclusions: These results highlight alcohol as a contributing factor for homicide victimization in the greatest urban center in South America, supporting public strategies and future research aiming to prevent homicides and violence related to alcohol consumption.

KeYwords: Ethanol. Violence. Homicide. Victimization. Blood alcohol concentration. 